\title{
Beter balanceren tussen over- en onderdiagnostiek bij Mycoplasma genitalium
}

Mycoplasma genitalium (Mg) is een seksueel overdraagbaar micro-organisme, maar de mate van pathogeniteit is vooralsnog onduidelijk. Bij persisterende klachten van uretritis en $\mathrm{PID}$ is Mg-diagnostiek aangewezen. Ongericht testen op Mg bij mensen zonder symptomen is nadrukkelijk af te raden om onnodige schade door over-diagnostiek en overbehandeling te voorkomen. Huisartsen: primum non nocere. Een herziening van de NHG-Standaarden Soa en PID wordt node gemist.

In het nascholingsartikel 'Mycoplasma genitalium, een nieuwe soa?' geven de auteurs adviezen over diagnostiek en therapie bij dit 'nieuwe' seksueel overdraagbare micro-organisme. ${ }^{1}$ De auteurs spreken zich naar mijn mening niet duidelijk genoeg uit over de handelwijze rondom testen op Mg bij asymptomatische personen. Gezien het feit dat ongericht testen en/ of screenen op Mg meer schade dan goed kan doen is testen op $\mathrm{Mg}$, indien er geen klachten zijn, ongewenst en terughoudendheid vereist. Dit is conform het advies uit de recente herziening (waarbij ook huisartsen waren betrokken) van de multidisciplinaire richtlijn soa uit 2018 met informatie over $\mathrm{Mg}$ in de vorm van een addendum. ${ }^{2}$

\section{MORE HARM THAN GOOD}

In hun aanbeveling rondom testen op Mg bij asymptomatische patiënten, bijvoorbeeld bij een soa check-up, schrijven de auteurs dat '... op basis van de nu beschikbare kennis geen goed wetenschappelijk onderbouwd antwoord te geven is, en het gerechtvaardigd lijkt om terughoudend te zijn met diagnostiek... Maar tegelijkertijd stellen zij '... omdat laboratoria dit nu toch al aanbieden en gegeven de prevalentie en overdrachtskans van Mycoplasma genitalium is dit beleid (asymptomatische patiënten ook testen op $\mathrm{Mg}$; JvB) te rechtvaardigen en is er wat voor te zeggen is om huisartsen samen met de patiënt vrij te laten in de keuze welke soa's bepaald worden.' Een veel stelliger advies is hier op zijn plaats. Er is geen bewijs aan de kant van de 'benefits': het natuurlijk beloop is onduidelijk, het overgrote merendeel van de infecties met $\mathrm{Mg}$ verloopt zonder klachten, het complicatierisico is laag, en de (kost-)effectiviteit van screening op Mg is onbekend. Aan de kant van de 'harms' valt er meer te melden (wat de auteurs nalaten): ernstige overdiagnostiek en overdiagnose, veel overbehandeling bij index en partners en een aanzienlijke versnelling van de antibioticaresistentie met voorspelbare schade aan individuele en publieke gezondheid. En dan hebben we het nog niet over de kosten voor patiënt en maatschappij, de onrust die opgespoorde asymptomatische $\mathrm{Mg}$-infecties in de relatie kunnen bewerkstelligen en de onduidelijkheid hoe de aanwezigheid van deze infectie door patiënt en partner(s) (en door de huisarts) geduid 'moet' worden. Moet alles wat kan..? Als Nederlandse huisartsen staan we voor zinnige, evidencebased diagnostiek en een terughoudend antibioticabeleid. We moeten ons dan ook zeker niet laten verleiden tot een ongevraagd en ongewenst aanbod aan soa-diagnostiek door laboratoria, ook al is dat middels huidige amplificatietechnieken makkelijk te realiseren (en een eenvoudige bron van inkomsten voor het lab). Vooralsnog niet doen dus. Ook een recente publicatie in het gezaghebbende tijdschrift The Lancet stelt ronduit dat testen van asymptomaten op $\mathrm{Mg}$ vooralsnog afgeraden moet worden. ${ }^{3}$

\section{TESTEN BIJ KLACHTEN}

Dat laat onverlet dat aanpassingen aan ons diagnostisch en therapeutisch handelen bij urethritis en PID gewenst is. ${ }^{4,5}$ De auteurs beschrijven dit ook helder: testen bij persisterende klachten en dan bij een Mg-infectie een vijfdaagse azitromycinekuur, waarbij de huidige seksuele partner(s) ook getest/ behandeld wordt (om re-infectie van de symptomatische patiënt te voorkomen) en een test-of-cure plaatsvindt. Bij de update van onze standaarden zijn er nog andere opties te exploreren zoals al testen (inclusief resistentiebepaling) bij initiële soa-diagnostiek bij klachten van urethritis en PID. Qua medicatie valt te overwegen korter en hoger te doseren voor $\mathrm{Mg}$ (azithromycine 1 gram dag 1 en daarna 2 dagen 500 mgr), iets dat onze Britse collega's adviseren in hun nieuwe richtlijn over Mg. Nationale en internationale richtlijnen over soa - ook de Multidisciplinaire richtlijn 2018 - zijn makkelijk toegankelijk via de professionele site van Soa Aids Nederland. ${ }^{6}$ -

Jan van Bergen, professor hiv en soa in de 1e lijn, Amsterdam Universitair Medisch Centrum; programmaleider Soa Aids Nederland; huisarts/ centrum infectieziektenbestrijding RIVM

\section{LITERATUUR}

1. Berkhout H, Van der Wel M. Mycoplasma genitalium, een nieuwe soa? Huisarts wet 2018;61(9):51-3.

Deze reactie is te vinden op www.henw.org bij het artikel 'Mycoplasma genitalium, een nieuwe soa?'. Daar staat ook de volledige literatuurlijst.

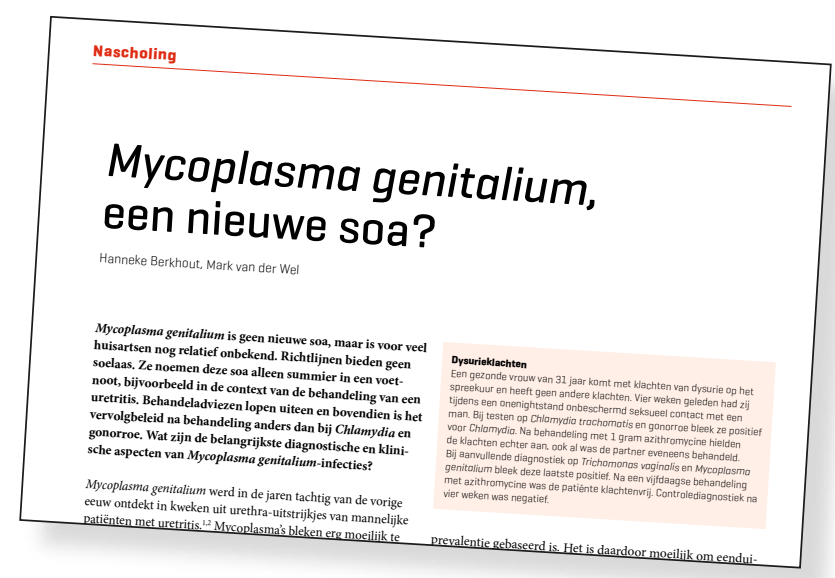

